\title{
Determination of the Efficiencies of Textile Firms Listed in Borsa İstanbul by Using DEA-Window Analysis
}

\author{
Mehmet APAN (https://orcid.org/0000-0001-9471-4810), Department of Business Administration, Karabük \\ University, Turkey; e-mail: mehmetapan@karabuk.edu.tr \\ Ihsan ALP (https://orcid.org/0000-0002-6306-5114), Department of Statistics, Gazi University, Turkey; e-mail: \\ ihsanalp@gazi.edu.tr
}

Ahmet ÖZTEL (https://orcid.org/0000-0002-9627-7850), Department of Management, Bartin University, Turkey; e-mail: ahmetoztel@gmail.com

\section{VZA-Pencere Analizi ile Borsa İstanbul'da Hisse Senetleri İşlem Gören Tekstil Firmalarının Etkinliklerinin Belirlenmesi}

\begin{abstract}
Global competition enables countries' advantageous sectors to stand out as an indicator of their economic power. The importance of these sectors may vary by country or the time period they operate in. The textile industry is one of the sectors that significantly contributes to Turkey's economic growth. Thus, it is important to monitor the financial activities of the firms in the textile sector as a performance indicator since it is evident that the financial efficiency of each company will contribute positively to the overall efficiency of the whole sector. In this study, the financial activities of 19 firms in the textile sector being traded on Borsa Istanbul (BIST) for the period 2008-2017 are examined. For efficiency analysis, DEA (Data Envelopment Analysis) -Window Analysis method was applied by using financial indicators of these companies. It was observed that the highest average efficiency value of the companies was realized in 2017 with $94.09 \%$. The average activity levels in other years were found to be in the range of $60 \%-90 \%$. In the empirical analysis, the efficiency values of the top five companies were determined to be at the level of $90 \%-100 \%$. DESA has achieved the most successful performance in average efficiencies with a score of 98.04 when the whole period is considered. SÖNMEZ and MENDERES firms have taken the second and the third places with scores of 97.40 and 94.74 , respectively. The close performances of the top three firms were also observed in three-years windows. However, in the three-year window analysis, SÖNMEZ ranked the first, DESA ranked the second and MENDERES ranked the third according to their average scores. One of the reasons for this small difference between the rankings is that, firstly, the firms' performances have been very close to each other, and secondly the effect of the low score (76.11) obtained by SÖNMEZ in 2008 has been diminished for the firm in the three-year window analysis. KARSU occupied the last place with the lowest average efficiency score in both rankings.
\end{abstract}

Keywords $\quad$ : Efficiency, Performance, Textile, DEA, Window Analysis.

JEL Classification Codes : C61, C67, L67.

\section{Öz}

Küresel rekabet ile ülkelerin ekonomik güçlerinin bir göstergesi olarak üstün oldukları sektörler öne çıkmaktadır. Bu sektörlerin önemi ülkeden ülkeye veya dönemsel olarak değişebilmektedir. Tekstil sektörü, Türkiye'nin ekonomik büyümesine önemli katkı sağlayan sektörlerden biridir. Tekstil sektöründeki firmaların finansal etkinliklerinin performans göstergesi olarak takip edilmesi önemlidir. Her bir firmanın finansal etkinliğinin, sektörün toplam etkinliğine olumlu katkı sağlayacağı aşikârdır. Bu çalışmada, Borsa İstanbul'da (BİST) hisse senetleri işlem gören 
tekstil sektöründeki 19 firmanın 2008-2017 dönemi için finansal etkinlikleri incelenmiştir. Etkinlik analizi için firmaların finansal göstergelerine göre VZA (Veri Zarflama Analizi)-Pencere Analizi yöntemi uygulanmıştır. Firmaların en yüksek ortalama etkinlik değerinin \%094,09 ile 2017 yılında gerçekleştiği görülmüştür. Diğer yıllardaki ortalama etkinlik düzeylerinin $\% 60-\% 90$ aralığında bulunduğu tespit edilmiştir. Ampirik analizlerde ilk 5 firmanın etkinlik değerlerinin \%90-\%100 aralığında olduğu belirlenmiştir. Yıllık etkinlik skor ortalamalarında, DESA 98.04 skoruyla en başarılı performansı elde etmiştir. Sırasıyla SÖNMEZ 97.40 ve MENDERES 94.74 ile ilk üç sırayı oluşturmuşlardır. İlk üç sıradaki firmaların birbirlerine yakın performansları üçer yıllık pencerelerde de gözlenmiştir. Fakat ortalama skorlarda, üçer yıllık pencere analizinde SÖNMEZ ilk sirada yer alırken, DESA ikinci ve MENDERES ise üçüncü olmuştur. Sıralamalar arasındaki bu küçük farklılığın sebeplerinden ilki performansların çok yakın seyretmesi, ikincisi ise 2008 yılında SÖNMEZ firmasının elde ettiği düşük puanın (76.11) etkisinin, üç yıllık pencere analizinde azalmış olmasıdır. KARSU ise her iki sıralamada da en düşük ortalama etkinlik skoru ile son sırada yer almıştır.

Anahtar Sözcükler $\quad$ : Etkinlik, Performans, Tekstil, VZA, Pencere Analizi.

\section{Introduction}

The textile industry has shifted its traditional production, which started in the early periods of history, to mass production with the Industrial Revolution. This has become an indispensable industrial sector in the industrialization process of many countries. In spite of the increasing competition, it continues to be an important industrial sector where a wide variety of products are produced with the support of technological development today. The textile sector is a labor-intensive and capital-intensive industry that includes enterprises engaged in yarn, weaving, knitting and textile-finishing operations (İSO, 2014: 1-52).

It has become a necessity for companies to manage their resources efficiently and productively. In this framework, financial efficiency measures are becoming increasingly important for firms to enter emerging markets, increase market share, and anticipate partners' profitability.

This study aims to determine the performance-based efficiencies of textile firms using financial data. Some of the financial indicators for the 2008-2017 period of the companies included in the analysis are summarized in Table 1.

\section{Table: 1}

Financial Information of Textile Firms (TL)

\begin{tabular}{lrrr}
\hline YEAR & SALES & NET INCOME & EQUITY \\
\hline 2008 & $2,948,068,178$ & $-94,438,298$ & $3,719,943,038$ \\
2009 & $2,674,111,017$ & $9,213,523$ & $3,603,272,404$ \\
2010 & $3,188,595,238$ & $60,707,954$ & $4,090,853,536$ \\
2011 & $3,991,904,989$ & $279,942,042$ & $5,036,984,985$ \\
2012 & $3,927,461,692$ & $39,816,255$ & $5,185,210,674$ \\
2013 & $4,251,960,426$ & $5,783,098,583$ \\
2014 & $4,729,472,580$ & $-12,973,701$ & $6,362,471,142$ \\
2015 & $4,832,433,670$ & $6,978,686,413$ & $2,941,825,316$ \\
2016 & $5,231,312,332$ & $179,74,386,236$ & $3,027,037,312$ \\
2017 & $6,698,745,431$ & $61,416,653$ & $2,981,220,689$ \\
\hline TOTAL & $42,474,065,553$ & $308,635,519$ & $3,100,949,769$ \\
\hline SOLIT, & & $1,085,951,650$ & $3,310,748,922$ \\
\end{tabular}

Source: <www.kap.org.tr>, 11.04.2019. 
After the introduction section, the second section summarizes domestic and foreign literature. In the third section, Window Analysis (a DEA based method) is explained. In the fourth section, the financial activity results for textile firms during the analysis period are explained. In the fifth section, the conclusions and suggestions for further research are included.

\section{Literature Review}

The DEA-Window analysis method has applications in the fields of banking, ports, economics, energy, tourism, and health care. Some of the domestic and foreign literature done in this framework is briefly summarized below.

Webb (2003) aimed to determine the effectiveness levels of retail banks in the UK by using the DEA-window analysis. A 1980-1995 period dataset was used for the analysis. It was determined that the long-term average tends to decline in efficiency.

Asmild et al. (2004) applied the DEA method by using the Malmquist Index to determine the time-varying efficiency of the five major banks that manage $90 \%$ of the Canadian banking sector with 1981-2000 period data. It was found that using the Malmquist Indexes with the DEA-window analysis in the measurement of efficiency yielded appropriate results.

The activity of container ports in the world was analyzed by Cullinane et al. (2004) with 200 observations from 1992-1999 data using the DEA-window analysis method. The results of the analysis obtained were evaluated comparatively.

Sufian and Majid (2007) conducted a DEA-window analysis to determine the relationship between commercial bank efficiency and stock prices in Singapore during 19932003. According to empirical analysis, Singapore commercial banks were found to be efficient at $95.4 \%$. It has been determined that there is a very small statistical response between stock prices and cost effectiveness.

Chung et al. (2008) aimed to model the production of the product mix for long-lasting efficiency and profitability, using DEA-window analysis for a semi-conductor factory in Taiwan.

Halkos and Tzeremes (2009a) aimed to determine the efficiencies of the economic growth of $25 \mathrm{EU}$ (European Union) countries by DEA-window analysis for the 1995-2005 period dataset. It was determined that the enlargement policies of the EU adversely affected the economic development of the former 15 EU Member States.

In the study of Halkos and Tzeremes (2009b), the 1980-2002 period data set was analyzed with the DEA-window analysis method in order to determine the relationship between national income and the environmental efficiencies of 17 OECD countries. It was 
found that increasing economic activities do not protect the environment, and therefore it is important in the development method as well as the development itself.

Kazley and Ozcan (2009) applied DEA-window analysis to determine the use and efficiency of electronic medical information of hospitals with the data obtained from the American Hospitals Association and the Health Information Management Systems Group.

Yang and Chang (2009) analyzed the activities of telecommunication companies in Taiwan with the 2001-2005 period dataset. From the empirical analyzes, the following conclusions were reached. With the acquisitions, high-scale efficiency is achieved in the short term. With a growing market share, the financial portfolio assists firms in reaching the best scale, and competition is increasing with the liberal market structure.

Al-Eraqi et al. (2010) assessed the effectiveness of 22 cargo ports in East Africa and the Middle East. The dataset covers the period 2000-2005. In this study, it was determined that the five major ports were inefficient, whereas the small ports were efficient.

Pulina et al. (2010) examined the size and efficiency relationship of the 20 regions of Italy. DEA-window analysis was used for the 2002-2005 data in the analysis. The hotels were compared in terms of technique and scale activities.

Park et al. (2011) aimed to determine the efficiencies of companies using DEAwindow analysis for the 2006-2010 period dataset for 20 large Korean construction companies.

Zhang et al. (2011) analyzed data from the 1980-2005 period in 23 developing countries in terms of total factor energy efficiency. According to the empirical analysis results, Botswana, Mexico, and Panama have been identified as the countries with the best energy efficiency.

Afzal and Lawrey (2012) attempted to determine comparatively the informationbased development levels of ASEAN-5 (5 Southeast Asian Countries) for the 2005-2010 period. The analysis variables are information, production, distribution, and usage. In the study, the highest average for knowledge acquisition was found in Indonesia with $97.63 \%$, the highest average for knowledge generation in Thailand with $91.09 \%$, the highest average for information dissemination was Singapore with $95.86 \%$, and the highest average for information use was the Philippines by $97.18 \%$.

Chou et al. (2012) applied DEA-window analysis to the 2005-2010 dataset to determine the country's science and technology efficiency levels. According to the empirical analysis, it was found that Japan is the most efficient country at the average efficiency level.

Pjevčević et al. (2012) measured the activities of the 5 harbors on the Danube River in Serbia. For this purpose, the 2001-2008 period dataset was analyzed. 
Kahveci et al. (2013) aimed to determine the performance of Turkish deposit banks by DEA-window analysis. For these purposes, a two-stage model was developed for the banks' 2006-2011 period data.

Sueyoshi et al. (2013) determined the environmental performance of coal-fired power plants in the USA by DEA-window analysis. For this, 1995-2007 period data were used in the analysis.

Wang et al. (2013) analyzed the 2000-2008 dataset to measure the environmental and energy efficiency of 29 administrative regions of China with the DEA-window analysis method. In this context, it was found that the eastern region had the highest efficiency, while the western region of China has the worst energy and environmental efficiency. It was also found that China's energy and environmental efficiency showed an overall increase in 2008 compared to 2000 .

In the study of Li (2014), DEA-window analysis was conducted using the 2000-2010 dataset to determine the tourism activity of 31 regions of China. According to the empirical analysis, the effectiveness of the tourism industry as a whole has increased, and the diversity of each region has been increasing. In eastern cities such as Beijing, Tianjin and Shanghai, tourist activity has been found to be less efficient in regions such as Jilin, Sichuan and Gansu in the high, middle and western regions.

Meng et al. (2014) analyzed the 1996-2011 dataset with DEA-window analysis to assess the complexity and inefficiency of the mixed energy consumption of 16 APEC member countries. 16 APEC countries have reached the conclusion that fossil fuels are still an important part of energy consumption.

Nguyen et al. (2014) used the 1995-2011 period dataset to examine profit efficiency and cost trends in the Vietnam banking sector through DEA-window analysis. Empirical findings indicate that state banks are more efficient than private banks. It has been determined that overall activity tends to increase during the analysis period. In the Vietnamese banking sector, it was found that cost efficiency was 0.90 , and profit efficiency was about 0.75 .

Řepková (2014a) aimed to determine the effectiveness of the Czech Republic banking sector. DEA-window analysis was applied to the 2003-2012 period dataset. According to empirical analysis, efficiency based on the constant rate of return is $70 \%-78 \%$, and the efficiency based on the variable rate of return is $84 \%-89 \%$.

Řepková (2014b) was targeted to estimate the effectiveness of the Slovak commercial banks using DEA-window analysis for the 2003-2012 data set. Large banks in the Slovak banking sector have been found to have low efficiency compared to small and medium-sized banks. On the other hand, average efficiency increased in the period of 2003-2008, but average efficiency decreased in the period of 2008 and 2010-2011. 
Wu et al. (2014) aimed to determine the economic cycle activity of 30 regions of China with 2005-2010 period data. It has been determined that sustainable development policies can be achieved through coordination between central and regional administrations.

In the Dyck (2015) study, the effectiveness of 6 ports in West Africa was determined by DEA-window analysis. In the study, it was determined that 4 of the 6 ports using the 2006-2012 period data maintained an average efficiency score of $76 \%$ or higher.

Kutlar et al. (2015a) aimed to determine the efficiencies of 31 railway companies throughout the world through DEA-window analysis. For this purpose, the 2000-2009 period data set was analyzed. DEA window analysis shows that all firms have a stable average efficiency level.

In Kutlar et al. (2015b), 23 DEA-window analysis was applied to measure the dynamic efficiency of the Turkish Bank for 2003-2012 period data. The average efficiency value for all banks was found to be the highest in windows covering the 2006-2009 and 2007-2010 periods.

Shawtari et al. (2015) aimed to differentiate the activities of Islamic bank and conventional bank groups by applying DEA-window analysis to the 1996-2011 dataset of banks in Yemen. In the analysis, it was found that efficiency in all of Yemen's banks tended to fall, while most conventional banks were stable but inefficient. On the other hand, it was found that Islamic banks are more efficient.

The effectiveness of the renewable energy capacity established by Storto and Capano (2015) in 31 European countries was determined by DEA-window analysis. In this study, the 2002-2011 period data was used. It was found that the installed capacity in the countries of the sample had very low levels of efficiency, and that a majority of them were inefficient.

In a study conducted by Al-Refaie et al. (2016), the efficiency and energy efficiency of the Jordanian industry sector, the Malmquist Index and DEA-window analysis, and the 1999-2013 period dataset was used. On the other hand, periodic efficiency differences were also identified.

Kaya and Cinar (2016) conducted an efficiency measurement with the hybrid MultiEvent DEA-window analysis model developed for 11 major banks operating in the Turkish banking sector for the 2003-2013 period data.

Ohe and Peypoch (2016) aimed to determine the efficiency of the Ryokans, which are traditional accommodation hotels in Japan, with the 2005-2012 period data through the DEA-window analysis method. According to the results of analysis, large ryokans were found to be more effective than small ryokans. 
Sharifian et al.'s (2017) study evaluated the efficacy measures of Shiraz University departments for the period 2009-2014. It was found that double-boundary DEA-window analysis gave more accurate results.

\section{Data and Methodology}

BIST has 24 companies operating in the textile sector. In this study, full data of 19 firms were obtained for the 2008-2017 period. Financial data was obtained from www.kap.org.tr and from the websites of the companies. Empirical analyses were made with the data of the companies. Mentioned below.

Table: 2

Names and Codes of Textile Firm

\begin{tabular}{|c|c|c|}
\hline & FIRMS & CODES \\
\hline 1 & Akın Tekstil A.Ş. & AKIN \\
\hline 2 & Arsan Tekstil Ticaret ve Sanayi A.Ş. & ARSAN \\
\hline 3 & Bilici Yatırım ve Ticaret A.Ş. & BİLiCI \\
\hline 4 & Birko Birleşik Koyunlulular Mensucat Ticaret ve Sanayi A.Ş. & BİRKO \\
\hline 5 & Birlik Mensucat Ticaret ve Sanayi İşletmesi A.Ş. & BIRLIK \\
\hline 6 & Bossa Ticaret ve Sanayi İşletmeleri A.Ş. & BOSSA \\
\hline 7 & Dagi Giyim Sanayi ve Ticaret A.Ș. & DAGİ \\
\hline 8 & Derimod Konfeksiyon Ayakkabı Deri Sanayi ve Ticaret A.Ş. & DERIMOD \\
\hline 9 & Desa Deri Sanayi ve Ticaret A.Ş. & DESA \\
\hline 10 & Esem Spor Giyim Sanayi ve Ticaret A.Ş. & ESEM \\
\hline 11 & Hateks Hatay Tekstil İşletmeleri A.Ş. & HATEKS \\
\hline 12 & Karsu Tekstil Sanayi ve Ticaret A.Ş. & KARSU \\
\hline 13 & Kordsa Global Endüstriyel İplik ve Kord Bezi Sanayi ve Ticaret A.Ş. & KORDSA \\
\hline 14 & Lüks Kadife Ticaret ve Sanayi A.Ş. & LÜKSKA \\
\hline 15 & Menderes Tekstil Sanayi ve Ticaret A.Ș. & MENDERES \\
\hline 16 & Söktaş Tekstil Sanayi ve Ticaret A.Ş. & SÖKTAŞ \\
\hline 17 & Sönmez Pamuklu Sanayi A.Ş. & SÖNMEZ \\
\hline 18 & Yataş Yatak ve Yorgan Sanayi ve Ticaret A.Ş. & YATAȘ \\
\hline 19 & Yünsa Yünlü Sanayi ve Ticaret A.Ș. & YÜNSA \\
\hline
\end{tabular}

The study evaluates the financial performance of the textile sector firms that are traded in BIST between 2008 and 2017 by calculating the efficiency scores using the DEAwindow method. For the DEA-window analysis method applied, the input and output factors are tabulated below (Kula \& Özdemir, 2007: 63-64; Kula et al., 2009: 195; Başkaya \& Avc1Öztürk, 2012: 184; Erdoğan \& Y1ld1z, 2015: 136; Çetin, 2006: 266).

Tablo: 3

Input and Output Factors for Evaluation

\begin{tabular}{lll}
\hline FACTORS & FORMULAS & INPUT/OUTPUT \\
\hline Current Ratio & Current Assets/Short Term Liabilities & Input \\
Acid Test Ratio & (Current Assets-Inventories)/Short Term Liabilities & Input \\
Financial Leverage Ratio & Liabilities/Total Assets & Input \\
Receivable turnover in days & Average Recievables*Days in the year/Sales & Input \\
Inventory turnover in days & Average Inventory*Days in the year/Cost of goods sold & Input \\
Net Profit Margin & Net Income/Sales & Output \\
Return on Assets & Net Income/Total Assets & Output \\
Return on Equity & Net Income/Equity & Output \\
\hline
\end{tabular}

\subsection{Data Envelopment Analysis}

A nonparametric technique known as Data Envelopment Analysis (DEA) was developed by Charnes, Cooper, and Rhodes (CCR, 1978) and was based on Farrell's (1957) efficiency measurement opinion. While Farrell's original idea is concerned with one input 
and one output, the DEA method of Charnes, Cooper, and Rhodes can relate to cases where organizations (i.e., decision-making units, (DMUs)) use multiple inputs to produce multiple outputs simultaneously. A DMU is defined as the concrete or intangible system responsible for transforming inputs into outputs, and whose performance is evaluated. Examples of such units to which DEA has been applied include nations, banks, hospitals, schools, airports, tax offices, libraries, universities or their departments, and also environmental and energy organizations (Emrouznejad et al., 2008; Ray, 2004; Cook \& Seiford, 2009; Sözen \& Alp, 2009; Alp \& Sözen, 2011). Note that one advantage of DEA is that it can be applied to nonprofit organizations participating in public programs.

DEA is a powerful new methodology for organizing and analyzing data and for identifying best-practice frontiers. The basic idea of DEA is to identify the most efficient decision-making unit/s among all DMUs. The most efficient DMU is called a pareto-optimal unit and is considered the standard for comparison for all other DMUs. DEA uses linear programming technique to determine the efficiency frontier. The points that lie on the frontier constitute the efficient companies' DMUs, and the inefficient companies' DMUs lie below the frontier.

\section{Figure: 1 \\ Comparison of Theoretical Frontier, DEA and Regression Line}

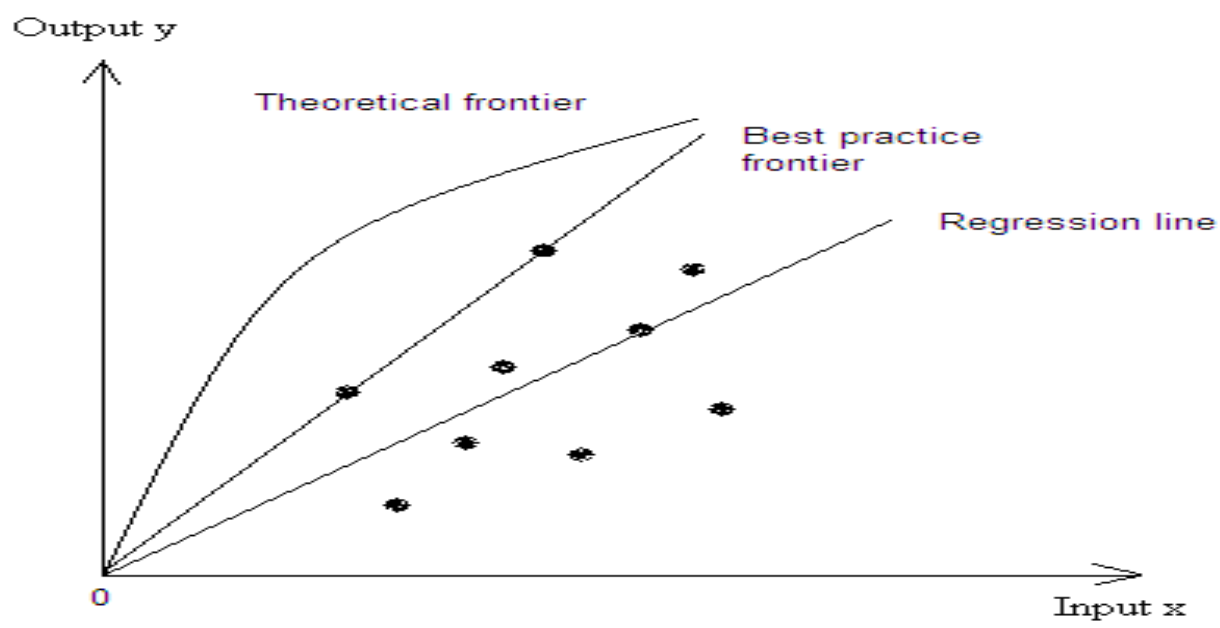

DEA has a major advantage over all other similar efficiency measurement techniques because of its methodology, which is directed to frontiers rather than central tendencies. Parametric approaches fit a regression line through the center of the data, while the DEA covers the data from the top with a piecewise linear surface. DEA focuses on every individual observation rather than averages and estimation of parameters associated with parametric approaches. 
The aim of DEA is to quantify the distance to the efficient frontier for every DMU. The measure of performance is expressed in the form of an efficiency score. After the evaluation of the relative efficiency of the present set of units, DEA shows how inputs and outputs have to be changed in order to maximize the efficiency of the target DMU. DEA suggests a benchmark for each inefficient DMU at the level of its individual mix of inputs and outputs.

DEA models can be classified by two criteria: type of scale effects and model orientation. The first criterion determines the assumptions concerning the scale effects accepted in the model (constant returns to scale (CRS), or variable returns to scale (VRS)). The model orientation approach indicates whether the objective is the minimization of input(s), such as the cost of production, or the maximization of a particular output such as profit. In this study, we used the output - oriented CCR (CRS) model, by which the efficiency score is determined by holding inputs constant and assessing to what extent outputs would have to be improved (increased) in order for a DMU to be considered efficient.

The dual form of the CCR (CRS) output-oriented model is as follows:

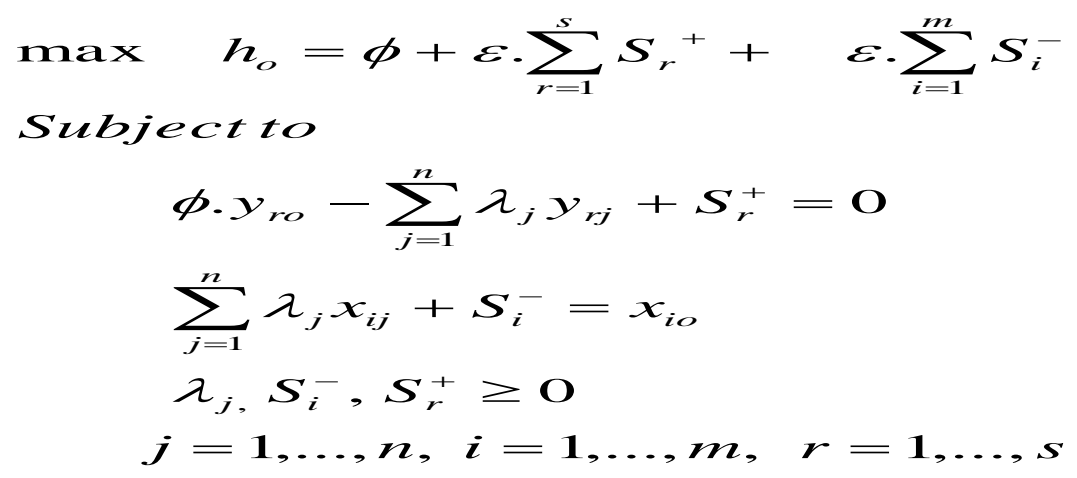

Where the subscript o represents the DMU being assessed and $h_{o}$ is the efficiency score of $\mathrm{DMU}_{\mathrm{o}}$. $\mathrm{x}_{\mathrm{ij}} \mathrm{y}_{\mathrm{rj}}$ denotes the input $\mathrm{i}$ and output $\mathrm{r}$ of $\mathrm{DMU} \mathrm{U}_{\mathrm{j}}$, respectively. $\varepsilon$ is an arbitrary small "non-Archimedian" number. $\boldsymbol{S}_{\boldsymbol{i}}, \boldsymbol{S}_{r}^{+}$are the slacks in the $\mathrm{i}^{\text {th }}$ and the $\mathrm{r}^{\text {th }}$ input and output, and n, m, and s are the number of DMUs, inputs, and outputs, respectively.

From the dual CCR model, output augmentation is accomplished through the variable $\phi$. If $\phi$ is greater than 1.0 (or 100) and/or the slacks are not zero, then the DMU under investigation is inefficient; to improve and shift the DMU towards onto the frontier, a proportional increase of $\phi$ for all outputs is required, followed potentially by an adjustment of individual slacks. 


\subsection{Window Analysis}

In many DEA applications, cross-sectional data are used and each DMU unit is observed only one time in the studies. If multi-period data exist in combination with the individual efficiency of each DMU, it is often important to perform a panel data analysis where the focus is on changes in efficiency over time. However, for this purpose, one approach to performing longitudinal analysis is to compare cross-sectional performance series across the number of time periods in the study. This approach introduces variability into the analysis because it treats the performance of a DMU in each time period as independent from its performance in the previous period. Also, with this approach, it is not feasible to ascertain trends in performance or to observe persistence of efficiency or inefficiency, whereas the window analysis approach corrects some of these problems. In such a setting, it is possible to perform DEA over time using a moving average analogue (of time series), where a DMU in each different time period is treated as a distinct DMU. Specifically, a DMU's performance in a particular period is contrasted with its performance in other periods in addition to the performance of the other DMUs (Charnes et al., 2004; Day et al., 2004) While ordinary DEA results table can be named as a "static table", a window analysis results table is regarded as a "dynamic table". analysis:

The following concepts and formulas can be used in an application of a window

$$
\begin{aligned}
& \mathrm{n}=\text { number of DMUs } \\
& \mathrm{k}=\text { number of periods } \\
& \mathrm{w}=\text { number of windows } \\
& \mathrm{p}=\text { length of windows }
\end{aligned}
$$

In this study, the number of DMUs (the number of firms, $n$ ) is 19 . The number of periods (k) is 10, as the years of observation are from 2008 to 2017. The performance of firms may be dependent on the previous two years, so the window length (p) is 3 . In this application,

$$
\begin{aligned}
& \text { \# of windows: } \mathrm{w}=\mathrm{k}-\mathrm{p}+1=10-3+1=8 \text {. } \\
& \text { \# of DMUs in each window: } \mathrm{w} * \mathrm{p}=8 * 3=24 \text {. } \\
& \text { \# of different DMUs: } \mathrm{n} * \mathrm{p} * \mathrm{w}=19 * 3 * 8=456 \text {. }
\end{aligned}
$$

The structure of Table 9 in appendix portrays the underlying framework of the window analysis. For the first window, AKIN firm is represented within the constraints of the DEA model as though it were a different DMU during the three-year $(2008,2009,2010)$ sample set of 19 DMUs. Hence, when a firm is evaluated for its year 2008 efficiency, its own performance data for years 2008, 2009, and 2010 are included in the constraint sets, 
along with similar performance data obtained from other nations for the years 2009 and 2010. Thus, the results of the first window consist of 24 scores under each of the columns 2008, 2009, and 2010, corresponding to each row of firms. Then the window is shifted one period, and an analysis is performed on the second three-year $(2009,2010$, and 2011) set of observations for the 19 DMUs. If there are more periods, then the process continues in this manner, shifting the window forward one period at a time.

\section{Results of Analysis: DEA-Window Application for the Determination of Textile Firms Efficiencies}

DEA-window analysis helps assess the activities of textile firms that perform as moving averages over different time periods. In this respect, DEA-window analysis extends the evaluation period and reference size of textile firms with a moving average. Thus, the discrimination power of the DEA method arises when textile firms increase the size of the evaluation. As shown in Table 4 below, when a new time dimension is added to each window, the first added time dimension is reduced. The first window (Window 1): It covers 2008, 2009, and 2010 years. In the second window (Window 2), 2008 will be lowered and the 2011-year window will be added. The third window (Window 3) will be considered to be 2010, 2011, and 2012. The fourth window (Window 4) will be considered to be 2011, 2012, and 2013. The fifth window (Window 5) will be considered to be 2012, 2013, and 2014. The analysis will take place until the eighth window (Window 8) 2015, 2016, and 2017 is analyzed.

Table: 4

Windows Breakdown

\begin{tabular}{llllllrl}
\hline WINDOWS & \multicolumn{7}{c}{ BREAKDOWN } \\
\hline Window 1 & 2008 & 2009 & 2010 & & & & \\
Window 2 & & 2009 & 2010 & 2011 & & & \\
Window 3 & & 2010 & 2011 & 2012 & & \\
Window 4 & & & 2011 & 2012 & 2013 & \\
Window 5 & & & & 2012 & 2013 & 2014 \\
Window 6 & & & & & 2013 & 2014 & 2015 \\
Window 7 & & & & & & 2014 & 2015 \\
Window 8 & & & & & & & 2016 \\
\hline
\end{tabular}

The annual and average activity values of textile firms covering the period 2008-2017 are presented in Table 5 below.

Table: 5

Average Efficiencies of Textile Firms (2008-2017)

\begin{tabular}{|c|c|c|c|c|c|c|c|c|c|c|c|}
\hline FIRMS & 2008 & 2009 & 2010 & 2011 & 2012 & 2013 & 2014 & 2015 & 2016 & 2017 & AVERAGE \\
\hline AKIN & 57.24 & 75.05 & 96.24 & 97.79 & 96.36 & 93.19 & 100.00 & 100.00 & 99.84 & 100.00 & 91.57 \\
\hline ARSAN & 61.06 & 69.66 & 85.35 & 100.00 & 100.00 & 100.00 & 100.00 & 94.76 & 99.14 & 100.00 & 91.00 \\
\hline BİLİCİ & 100.00 & 95.28 & 100.00 & 85.36 & 75.18 & 77.92 & 100.00 & 88.59 & 74.91 & 97.33 & 89.46 \\
\hline BİRKO & 54.36 & 55.38 & 69.77 & 79.17 & 88.74 & 73.77 & 70.87 & 70.00 & 84.49 & 100.00 & 74.66 \\
\hline BİRLIK & 55.40 & 85.30 & 88.49 & 84.21 & 100.00 & 51.40 & 58.76 & 89.12 & 80.51 & 100.00 & 79.32 \\
\hline BOSSA & 82.35 & 66.97 & 70.76 & 86.22 & 80.78 & 79.88 & 83.91 & 96.26 & 99.46 & 90.75 & 83.73 \\
\hline DAGİ & 51.54 & 62.37 & 80.61 & 100.00 & 73.57 & 58.38 & 75.85 & 98.54 & 70.43 & 53.08 & 72.44 \\
\hline DERIMMOD & 47.71 & 48.04 & 59.63 & 83.08 & 98.81 & 100.00 & 100.00 & 100.00 & 100.00 & 99.23 & 83.65 \\
\hline DESA & 100.00 & 99.94 & 99.14 & 100.00 & 100.00 & 94.02 & 100.00 & 99.88 & 87.47 & 100.00 & 98.04 \\
\hline ESEM & 64.34 & 18.07 & 100.00 & 100.00 & 96.89 & 100.00 & 99.46 & 76.62 & 56.46 & 100.00 & 81.18 \\
\hline HATEKS & 79.10 & 84.59 & 94.40 & 99.30 & 91.57 & 83.07 & 80.43 & 86.47 & 100.00 & 100.00 & 89.89 \\
\hline KARSU & 49.90 & 50.62 & 63.90 & 67.08 & 69.07 & 64.95 & 67.38 & 75.44 & 76.36 & 88.84 & 67.35 \\
\hline KORDSA & 56.08 & 72.28 & 79.35 & 93.10 & 91.23 & 99.05 & 100.00 & 87.63 & 90.83 & 97.38 & 86.69 \\
\hline
\end{tabular}


Apan, M. \& İ. Alp \& A. Öztel (2019), "Determination of the Efficiencies of Textile Firms Listed in Borsa İstanbul by Using DEA-Window Analysis", Sosyoekonomi, Vol. 27(42), 107-128.

\begin{tabular}{|c|c|c|c|c|c|c|c|c|c|c|c|}
\hline LÜKSKA & 46.54 & 58.84 & 79.12 & 87.06 & 96.77 & 67.29 & 76.82 & 72.95 & 84.36 & 77.14 & 74.69 \\
\hline MENDERES & 75.79 & 93.74 & 97.38 & 100.00 & 86.74 & 99.38 & 99.68 & 94.71 & 100.00 & 100.00 & 94.74 \\
\hline SÖKTAŞ & 53.78 & 59.48 & 69.97 & 89.76 & 86.89 & 97.47 & 97.74 & 100.00 & 100.00 & 97.01 & 85.21 \\
\hline SÖNMEZ & 76.11 & 100.00 & 100.00 & 100.00 & 97.87 & 100.00 & 100.00 & 100.00 & 100.00 & 100.00 & 97.40 \\
\hline YATAŞ & 53.78 & 60.47 & 61.95 & 63.46 & 61.40 & 74.63 & 80.99 & 91.71 & 92.12 & 100.00 & 74.05 \\
\hline YÜNSA & 63.41 & 65.77 & 72.03 & 81.66 & 80.44 & 88.63 & 96.82 & 78.36 & 62.07 & 87.05 & 77.62 \\
\hline AVERAGE & 64.66 & 69.57 & 82.53 & 89.33 & 88.02 & 84.37 & 88.88 & 89.53 & 87.29 & 94.09 & 83.83 \\
\hline
\end{tabular}

According to the average activity values of textile firms, DESA first with $98.04 \%$, SÖNMEZ second with $97.40 \%$, MENDERES third with $94.74 \%$, AKIN with fourth with $91.57 \%$, and ARSAN $91.00 \%$ is in fifth place with scores. These firms are followed by HATEKS, BİLICI, KORDSA, SÖKTAŞ, BOSSA, DERIMOD, ESEM, BIRLIK, YÜNSA, LÜKSKA, BIRKO, YATAS, DAGI and KARSU, respectively. On the other hand, the years covering the average efficiency values of the textile companies had different values. The highest average value was realized as $94.09 \%$ for the year 2017. In second place, 2015 received $89.53 \%$. It is ranked $89.33 \%$ in $2011,88.88 \%$ in $2014,88.02 \%$ in $2012,87.29 \%$ in $2016,84.37 \%$ in 2013 , and $82.53 \%$ in 2010 , respectively. The distribution of efficient firms over the years according to these results is presented in Table 6 below.

Table: 6

Distribution of Efficient Firms Over the Years (2008-2017)

\begin{tabular}{cccccccccc}
\hline $\mathbf{2 0 0 8}$ & $\mathbf{2 0 0 9}$ & $\mathbf{2 0 1 0}$ & $\mathbf{2 0 1 1}$ & $\mathbf{2 0 1 2}$ & $\mathbf{2 0 1 3}$ & $\mathbf{2 0 1 4}$ & $\mathbf{2 0 1 5}$ & $\mathbf{2 0 1 6}$ & $\mathbf{2 0 1 7}$ \\
\hline BİLİCI & SÖNMEZ & BİLİCI & ARSAN & ARSAN & ARSAN & AKIN & AKIN & DERIMOD & AKIN \\
DESA & & ESEM & DAGİ & BİRLIK & DERIMOD & ARSAN & DERIMOD & HATEKS & ARSAN \\
& & SÖNMEZ & DESA & DESA & ESEM & BİLICI & SÖKTAŞ & MENDERES & BİRKO \\
& & & ESEM & & SÖNMEZ & DERIMOD & SÖNMEZ & SÖKTAŞ & BİRLIK \\
& & & MENDERES & & & DESA & & SÖNMEZ & DESA \\
& & & SÖNMEZ & & & KORDSA & & & ESEM \\
& & & & & & SÖNMEZ & & & HATEKS \\
& & & & & & & & & MENDERES \\
& & & & & & & & & SÖNMEZ \\
& & & & & & & & YATAŞ \\
\hline
\end{tabular}

BİLICI and DESA for the year of 2008, SÖNMEZ for the year of 2009, BİLICI, ESEM, and SÖNMEZ for the year of 2010, ARSAN, DAGI, DESA, ESEM, MENDERES, and SÖNMEZ for the year of 2011, ARSAN, BİRLIK, and DESA for the year 2012, ARSAN, DERIMOD, ESEM, and SÖNMEZ for the year 2013 and 7 firms for the year 2014, AKIN, ARSAN, BİLICI, DERIMOD, DESA, KORDSA, and SÖNMEZ and for the year 2015, AKIN, DERIMOD, SÖKTAŞ, SÖNMEZ were found efficient. In 2016 DERIMOD, HATEKS, MENDERES, SÖKTAŞ, SÖNMEZ and in 201710 firms AKIN, ARSAN, BIRKO, BIRLIK, DESA, ESEM, HATEKS, MENDERES, SÖNMEZ, and YATAŞ were found efficient.

The performances of the textile firms according to the average values of the activity values in each window are detailed below in Table 7 .

When all the windows are examined, SÖNMEZ firm has the highest average efficiency score with $98.74 \%$ points. This is followed by $98.08 \%$ by DESA, $95.71 \%$ by MENDERES, $94.07 \%$ by AKIN and $93.26 \%$ by ARSAN. These five firms are distinguished from other firms by the highest average efficiency value and constitute $90 \%-100 \%$ of the group. In the second group, the HATEKS firm, the KORDSA firm, the BILICI firm, the DERIMOD firm, the ESEM firm and the BOSSA account for $89.75 \%, 88.76 \%, 87.24 \%$, 
$86.09 \%, 84.67 \%$, and $83.31 \%$ respectively, with $80 \%-90 \%$ of the total. The third group is BİRLİK 79.33\%, YÜNSA 79.16\%, LÜKSKA 76.98\%, DAGİ 76.00\%, BİRKO $74.83 \%$ and YATAŞ $73.45 \%$, respectively. Efficiency score is 67.24 points for KARSU.

Table: 7

Average Efficiency Scores For Each Textile Firm in Each Window

\begin{tabular}{|c|c|c|c|c|c|c|c|c|c|}
\hline FIRMS & $\begin{array}{l}2008 \\
2009 \\
2010 \\
\end{array}$ & $\begin{array}{l}2009 \\
2010 \\
2011\end{array}$ & $\begin{array}{l}2010 \\
2011 \\
2012 \\
\end{array}$ & $\begin{array}{l}2011 \\
2012 \\
2013 \\
\end{array}$ & $\begin{array}{l}2012 \\
2013 \\
2014 \\
\end{array}$ & $\begin{array}{l}2013 \\
2014 \\
2015 \\
\end{array}$ & $\begin{array}{l}2014 \\
2015 \\
2016 \\
\end{array}$ & $\begin{array}{l}2015 \\
2016 \\
2017 \\
\end{array}$ & AVERAGE \\
\hline SÖNMEZ & 92.04 & 100.00 & 98.82 & 100.00 & 99.05 & 100.00 & 100.00 & 100.00 & 98.74 \\
\hline DESA & 100.00 & 99.10 & 100.00 & 100.00 & 96.98 & 96.98 & 96.34 & 95.26 & 98.08 \\
\hline MENDERES & 85.14 & 100.00 & 94.39 & 96.48 & 95.49 & 99.76 & 97.05 & 97.34 & 95.71 \\
\hline AKIN & 70.30 & 92.86 & 99.98 & 100.00 & 92.73 & 96.82 & 99.90 & 99.94 & 94.07 \\
\hline ARSAN & 76.78 & 82.68 & 92.68 & 100.00 & 100.00 & 97.98 & 97.05 & 98.87 & 93.26 \\
\hline HATEKS & 83.48 & 92.98 & 97.15 & 93.50 & 83.04 & 82.09 & 90.39 & 95.36 & 89.75 \\
\hline KORDSA & 61.62 & 82.01 & 92.35 & 97.82 & 96.22 & 95.90 & 94.63 & 89.53 & 88.76 \\
\hline BİLİCİ & 96.85 & 94.84 & 86.24 & 82.48 & 82.80 & 87.62 & 85.58 & 86.43 & 87.86 \\
\hline SÖKTAȘ & 54.46 & 75.33 & 79.96 & 94.81 & 98.14 & 98.01 & 98.70 & 98.51 & 87.24 \\
\hline DERIMOD & 43.36 & 57.96 & 88.33 & 99.80 & 100.00 & 100.00 & 100.00 & 99.23 & 86.09 \\
\hline ESEM & 60.80 & 72.69 & 96.89 & 100.00 & 99.85 & 92.17 & 76.98 & 78.00 & 84.67 \\
\hline BOSSA & 68.22 & 74.95 & 83.71 & 86.77 & 77.25 & 85.60 & 96.01 & 93.95 & 83.31 \\
\hline BİRLİK & 81.84 & 81.75 & 88.48 & 80.79 & 69.66 & 68.84 & 80.97 & 82.32 & 79.33 \\
\hline YÜNSA & 66.62 & 70.52 & 77.21 & 84.72 & 88.27 & 91.18 & 80.74 & 74.04 & 79.16 \\
\hline LÜKSKA & 54.88 & 70.67 & 94.67 & 90.23 & 78.14 & 71.28 & 77.63 & 78.37 & 76.98 \\
\hline DAGİ & 56.09 & 86.30 & 89.72 & 79.40 & 64.94 & 76.69 & 81.57 & 73.31 & 76.00 \\
\hline BİRKO & 58.04 & 67.17 & 79.85 & 84.53 & 75.66 & 71.27 & 79.83 & 82.32 & 74.83 \\
\hline YATAŞ & 59.03 & 60.29 & 62.88 & 65.61 & 71.77 & 87.12 & 87.68 & 93.22 & 73.45 \\
\hline KARSU & 48.56 & 56.17 & 73.32 & 72.01 & 64.90 & 69.99 & 72.07 & 80.87 & 67.24 \\
\hline
\end{tabular}

According to the results of window analysis, the ranking of textile companies according to their activity results throughout the whole period is presented below in Table 8 .

Table: 8

Textile Firms Efficiency (2008-2017)

\begin{tabular}{|c|c|c|c|c|}
\hline FIRMS & MEAN & STANDART DEVIATION & RANGE & RANK \\
\hline SÖNMEZ & 98.88 & 4.54 & 23.89 & 1 \\
\hline DESA & 97.83 & 4.38 & 14.23 & 2 \\
\hline MENDERES & 96.18 & 6.35 & 24.21 & 3 \\
\hline AKIN & 94.73 & 10.59 & 42.76 & 4 \\
\hline ARSAN & 94.00 & 11.30 & 38.94 & 5 \\
\hline HATEKS & 90.89 & 8.17 & 20.90 & 6 \\
\hline KORDSA & 89.49 & 11.51 & 43.92 & 7 \\
\hline SÖKTAŞ & 88.49 & 15.08 & 47.79 & 8 \\
\hline BİLİCI் & 88.46 & 10.38 & 29.79 & 9 \\
\hline DERIMOD & 87.63 & 20.57 & 59.71 & 10 \\
\hline ESEM & 84.77 & 24.23 & 81.93 & 11 \\
\hline BOSSA & 84.46 & 10.55 & 41.03 & 12 \\
\hline BİRLİK & 80.87 & 17.61 & 50.12 & 13 \\
\hline YÜNSA & 79.11 & 11.08 & 38.16 & 14 \\
\hline LÜKSKA & 77.36 & 13.06 & 53.46 & 15 \\
\hline BİRKO & 76.87 & 12.74 & 48.26 & 16 \\
\hline YATAS & 76.06 & 15.09 & 46.22 & 17 \\
\hline DAGİ & 74.36 & 16.83 & 51.23 & 18 \\
\hline KARSU & 69.27 & 11.59 & 42.50 & 19 \\
\hline
\end{tabular}

SÖNMEZ (98.88\%), DESA (97.83\%), MENDERES (96.18\%), and are the three firms with the highest average activity between 2008 and 2017, respectively. According to the average efficiency, the least variability is DESA (4.38), SÖNMEZ (4.54), and MENDERES (6.35) units from the smallest to the largest. In the event evaluation, the smallness of the variability measures is a desirable condition with the size of the average. 
The range order is DESA (14.23), SÖNMEZ (23.89), and MENDERES (24.21) units, special evaluations can be made for each company using Table 8. Table 9, which contains the details, is attached in appendix.

\section{Graphic: 1 \\ Textile Firms' Efficiencies (2008-2017)}
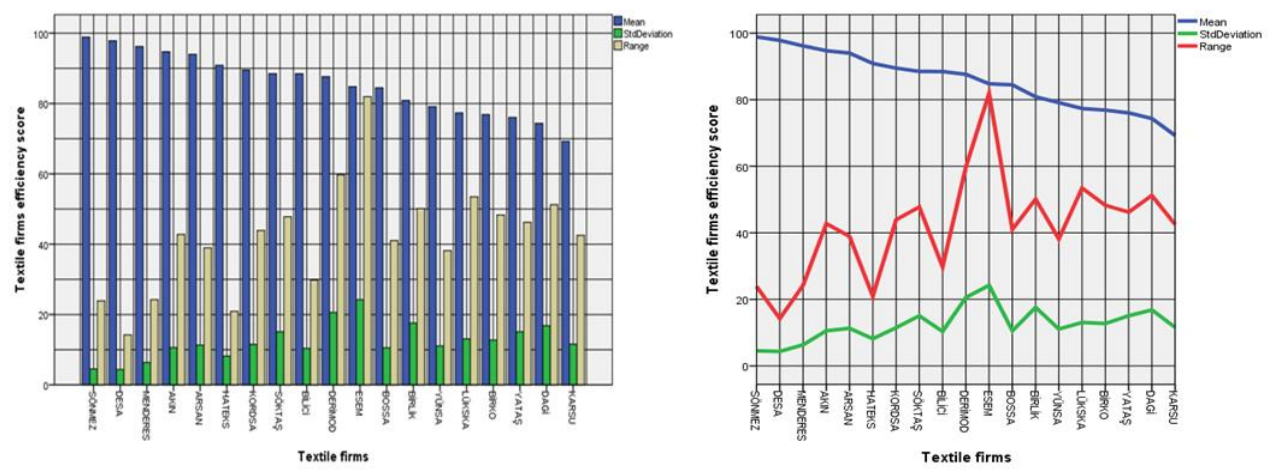

It is possible to assess the stability and trend of performance of every firm from Graphic 2 (a,b,c,d). Also, if a DMU is a part of a chain, on the basis of years, then it is possible to monitor the trends and changes in the chain as well.

Trends of performance of a DMU can be said to fall under one of the following four situations:

- stationary trend,

- continuously or non-continuously increasing trend,

- continuously or non-continuously decreasing trend,

- and a very wavy trend.

Obviously, in the above-mentioned cases, the preferred situation is a stationary trend with $100 \%$ performance score. In this time mean of performance of DMU will be 100, and standard deviation and range will be 0 . Unfortunately, there is no DMU that provides this situation in Table 8.

DMUs have a continuous or non-continuous increasing trend of performance are the following: SÖNMEZ, MENDERES, AKIN, ARSAN, DERIMOD, BİLİCİ, KORDSA, BOSSA, DAGİ, KARSU and YATAŞ (look Graphic 2).

The DMU that has a continuous or non-continuous decreasing trend of performance are the following: DESA, SÖKTAŞ, BİRLIK (look Graphic 2).

DMUs that have wavy, very variable trends of performance are the following: ESEM, LÜKSKA, BİRKO, YÜNSA and HATEKS (look Graphic 2). 


\section{Graphic: 2}

Textile Firms' Efficiencies (2008-2017)

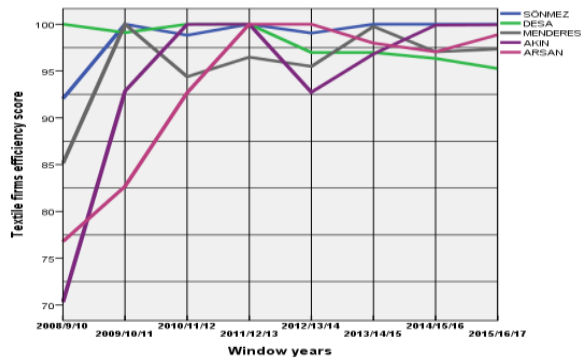

( a )

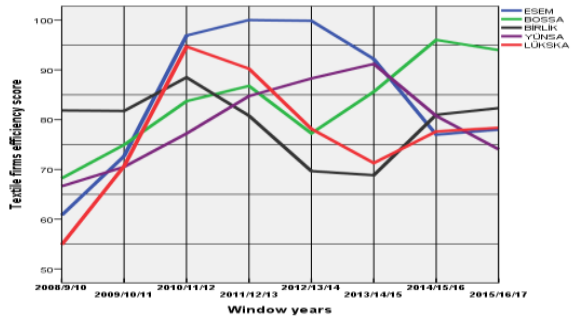

(c)

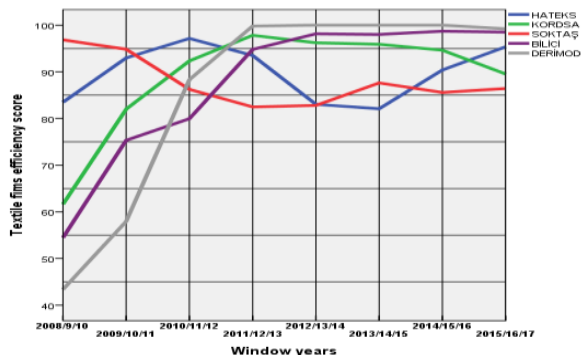

( $b$ )

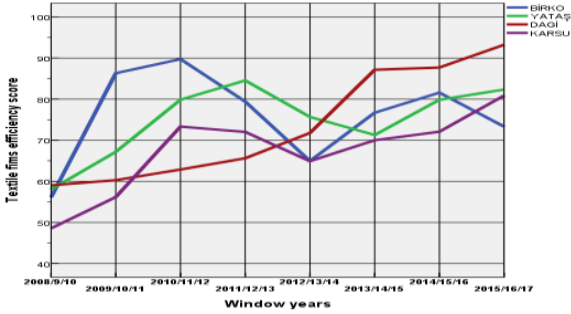

( d )

A boxplot of the performance scores of the firms reflects variability, homogeneity, and skewing in scores. Firms with a wide range means having non-homogenous distribution - for example, BİRLIK, DAGİ, LÜKSKA, ESEM, SÖKTAŞ, and YATAŞ firms. SÖNMEZ, DESA, ARSAN, AKIN firms make up a homogeneous group with less variability excluding outliers (look Graphic 3).

Graphic: 3

\section{Boxplot of Textile firms' Efficiencies}

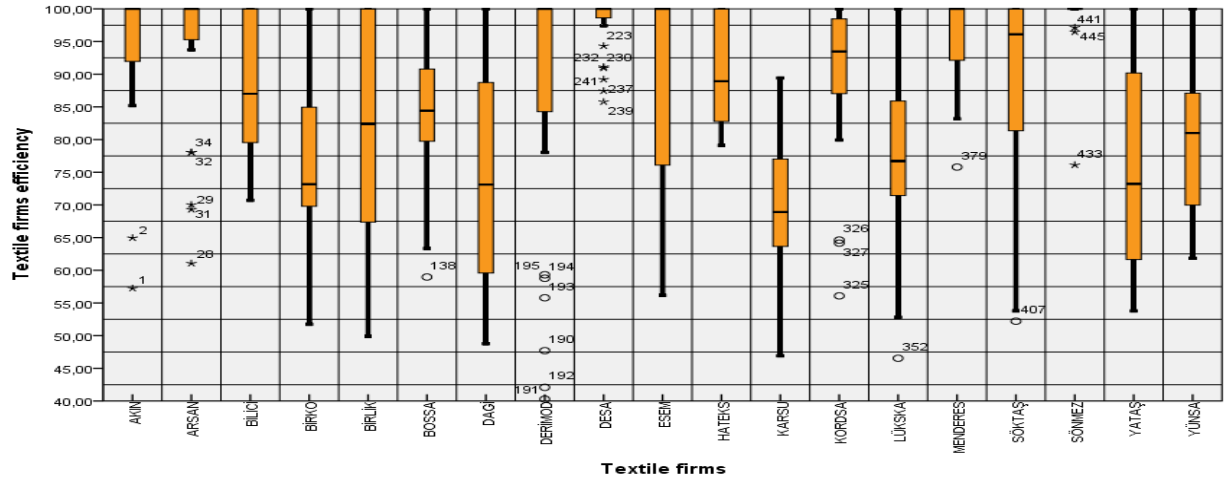


Again, if we assume that all DMUs are a part of a chain on the basis of year, then it is seen from Table 9 that there is an increasing trend (from the last right side of Table 9).

Performance scores for all DMUs, when all firms and all years are considered together, the general mean of efficiency scores is $85.77 \%$, and the standard deviation and range are 15.79 and 81.93 units, respectively (at right bottom of Table 9).

\section{Conclusion}

Turkish Textile Sector is one of the sectors that have a significant impact on the growth of the national economy in terms of the added value it provides, employment, production and export levels. Turkey's progress in world economic competition between countries is a matter directly related to the performance of the textile industry. Within this framework, the productivity and efficiency levels of the companies operating in the Textile Sector should be measured financially. Thus, determining the financial performance of firms will help them to continue their activities in a changing competitive environment.

In this study, data drawn from the period of 2008-2017 for 19 textile companies operating in the BIST textile sector were used. Data were obtained annually. Efficiency levels of firms were determined by applying the DEA-window analysis method to the dataset. DEA-window analysis is based on the moving average method.

The factors used in similar studies were taken into consideration to determine the performance of textile firms by DEA-window analysis. In the study, while input-output factors determine for DEA-window analysis method financial ratios utilized from Kula and Özdemir (2007), Kula et al. (2009), Başkaya and Avcı-Öztürk (2012), Erdoğan and Yıldız (2015) and Çetin (2006).

In the study, it is seen that the average efficiency values of textile firms have increased by years. In this framework, the highest average efficiency value was achieved in the $94.09 \%$ 2017. In other years, an average efficiency of $60 \%-90 \%$ was achieved.

When all windows in the DEA-Window analysis were examined, 98.04\% of DESA, 97.40\% of SÖNMEZ, $94.74 \%$ of MENDERES, $91.57 \%$ of AKIN, and $91.00 \%$ of ARSAN had the highest average efficiency values. It was determined that these firms constitute the first 5 of $90 \%-100 \%$ group.

A significant gap will be filled by this study because it is the first time that the textile industry in Turkey has been examined using the DEA-Window analysis method. In addition, the difference in work and the contribution to the literature are twofold. The first contribution is to evaluate the financial activities of textile firms with DEA-Window analysis over the 10 -year period. Secondly, the activities of textile firms are evaluated according to window periods. Analyses in the study were made only for the textile sector. By differentiating the research period, it may be possible to obtain more general results. 
Apan, M. \& İ. Alp \& A. Öztel (2019), "Determination of the Efficiencies of Textile Firms Listed in Borsa İstanbul by Using DEA-Window Analysis”, Sosyoekonomi, Vol. 27(42), 107-128.

\section{References}

Afzal, M.N. \& R. Lawrey (2012), “A Measurement Framework for Knowledge-Based Economy (KBE) Efficiency in ASEAN: A Data Envelopment (DEA) Window Approach", International Journal of Business and Management, 7(18), 57-68.

Al-Eraqi, A.S. \& A. Mustafa \& A.T. Khader (2010), “An extended DEA windows analysis: Middle East and East African seaports", Journal of Economic Studies, 37(2), 208-218.

Alp, İ. \& A. Sözen (2011), “Efficiency assessment of Turkey’s carbonization index”, Energy Sources, 33(18), 1678-1691.

Al-Refaie, A. \& M. Hammad \& M.-H. Li (2016), "DEA window analysis and Malmquist index to assess energy efficiency and productivity in Jordanian industrial sector", Energy Efficiency, 9, 1299-1313.

Asmild, M. \& J.C. Paradi \& V. Aggarwall \& C. Schaffnit (2004), "Combining DEA Window Analysis with the Malmquist Index Approach in a Study of the Canadian Banking Industry", Journal of Productivity Analysis, 21(1), 67-89.

Başkaya, Z. \& B. Avc1-Öztürk (2012), "Measuring Financial Efficiency of Cement Firms Listed in Istanbul Stock Exchange via Fuzzy Data Envelopment Analysis", Muhasebe ve Finansman Dergisi, 54, 175-188.

Charnes, A. \& W. Cooper \& A. Lewin \& L. Seiford (2004), Data Envelopment Analysis: Theory Methodology and Applications, Massachusetts, USA.

Charnes, A. \& W.W. Cooper \& E. Rhodes (1978), "Measuring the efficiency of decision-making units", European Journal of Operational Research, 2, 429-444.

Chou, Y.-C. \& C.-C. Sun \& H.-Y. Yen (2012), "Evaluation of human resources in science and technology by using dynamic Malmquist index approach and window analysis", African Journal of Business Management, 6(14), 5004-5013.

Chung, S.-H. \& A.H.-I. Lee \& H.-Y. Kang \& C.-W. Lai (2008), “A DEA window analysis on the product family mix selection for a semiconductor fabricator", Expert Systems with Application, 35, 379-388.

Cook, W.D. \& L. Seiford (2009), "Data envelopment analysis (DEA) - Thirty years on”, European Journal of Operational Research, 192(1), 1-17.

Cullinane, K. \& D.-W. Song \& P. Ji \& T.-F. Wang (2004), “An Application of DEA Windows Analysis to Container Port Production Efficiency”, Review of Network Economics, 3(2), 184-206.

Çetin, A.C. (2006), “Türk Tekstil Sektörü ve Türk Tekstil Firmalarının Etkinlik Düzeylerinin Belirlenmesi”, Afyon Kocatepe Üniversitesi İ̈BF Dergisi, 8(2), 255-278.

Day, D. \& A. Lewin \& R. Salazar (2004), "Strategic leaders in the U.S. brewing industry: A DEA window analysis", in: A. Charnes \& W.W. Cooper \& A.Y. Lewin \& L.M. Seiford (Eds.), Data Envelopment Analysis: Theory, Methodology and Applications, Boston/Dordrecht/London: Kluwer Academic.

Dyck, G.K. (2015), “Assessment of Port Efficiency in West Africa Using Data Envelopment Analysis", American Journal of Industrial and Business Management, 5, 208-218.

Emrouznejad, A. \& B. Parker \& G. Tavares (2008), "Evaluation of research in efficiency and productivity: A survey and analysis of the first 30 years of scholarly literature in DEA", Socio-Economic Planning Sciences, 42(3), 151-157. 
Apan, M. \& İ. Alp \& A. Öztel (2019), "Determination of the Efficiencies of Textile Firms Listed in Borsa İstanbul by Using DEA-Window Analysis", Sosyoekonomi, Vol. 27(42), 107-128.

Erdoğan, M. \& B. Yıldız (2015), "Sağlık İşletmelerinde Finansal Oranlar Aracılığıyla Performans Ölçümü: Hastanelerde Bir Uygulama”, Kafkas Üniversitesi İIBF Dergisi, 6(9), 129-148.

Farrell, M.J. (1957), “The measurement of productive efficiency", Journal of the Royal Statistical Society, Series A, General, 120, 253-281.

Halkos, G.E. \& N.G. Tzeremes (2009a), "Economic efficiency and growth in the EU enlargement", Journal of Policy Modeling, 31, 847-862.

Halkos, G.E. \& N.G. Tzeremes (2009b), “Exploring the existence of Kuznets curve in countries' environmental efficiency using DEA window analysis", Ecological Economics, 68, 2168-2176.

İSO - İstanbul Sanayi Odası (2014), Tekstil İmalatı Sanayi, No: 2014/4, İstanbul: İstanbul Sanayi Odası Yayınları.

Kahveci, E. \& Y. Celen \& İ.H. Ekşi (2013), "Türk Mevduat Bankalarının Performansının VZA Pencere Analizi İle Belirlenmesi”, Bankacllar Dergisi, 24 (86), 53-66.

KAP - Kamu Aydınlatma Platformu (2019), <www.kap.org.tr>, 11.04.2019.

Kaya, T. \& Y. Cinar (2016), “Analyzing Internal Efficiency Dynamics of Turkish Banks: Activity Based Multi-Objective Dynamic DEA Model and Its Application”, The Journal of Applied Business Research, 32(3), 729-746.

Kazley, A.S. \& Y.A. Ozcan (2009), "Electronic medical record use and efficiency: A DEA and windows analysis of hospitals", Socio-Economic Planning Sciences, 43, 209-216.

Kula, V. \& L. Özdemir (2007), "Çimento Sektöründe Göreceli Etkinsizlik Alanlarının Veri Zarflama Analizi Yöntemi ile Tespiti”, Afyon Kocatepe Üniversitesi IIIBF Dergisi, 9(1), 55-70.

Kula, V. \& T. Kandemir \& L. Özdemir (2009), "VZA Malmquist Toplam Faktör Verimlilik Ölçüsü: İMKB'ye Koteli Çimento Şirketleri Üzerine Bir Araştırma”, Sosyal Ekonomik Araştırmalar Dergisi, 9(17), 187-202.

Kutlar, A. \& A. Kabasakal \& A. Babacan (2015a), "Dynamic Efficiency of Turkish Banks: a DEA Window and Malmquist Index Analysis for the Period of 2003-2012”, Sosyoekonomi, 23(24), 71-97.

Kutlar, A. \& A. Kabasakal \& P. Torun (2015b), "Dynamic Efficiency Analysis of World Railway Firms: A DEA-Window Analysis with Malmquist Index", Anadolu Üniversitesi Sosyal Bilimler Dergisi, 15(1), 27-41.

$\mathrm{Li}$, B. (2014), "Analysis of the efficiency of regional tourism based on DEA window technology", Chinese Journal of Population Resources and Environment, 12(4), 354-360.

Meng, F. \& P. Zhou \& D. Zhou \& Y. Bai (2014), "Inefficiency and Congestion Assessment of Mix Energy Consumption in 16 APEC Countries by using DEA Window Analysis", Energy Procedia, 61, 2518-2523.

Nguyen, T.P. \& E. Roca \& P. Sharma (2014), "How efficient is the banking system of Asia's next economic dragon? Evidence from rolling DEA windows", Applied Economics, 46(22), 2665-2684.

Ohe, Y. \& N. Peypoch (2016), "Efficiency analysis of Japanese Ryokans: A window DEA approach", Tourism Economics, 22(6), 1261-1273.

Park, J.-L. \& S.-S. Kim \& S.-Y. Choi \& J.-H. Kim \& J.-J. Kim (2011), "Measuring Relative Efficiency of Korean Construction Company using DEA/Window", International Journal of Civil, Environmental, Structural, Construction and Architectural Engineering, 5(12), 691-695. 
Apan, M. \& İ. Alp \& A. Öztel (2019), "Determination of the Efficiencies of Textile Firms Listed in Borsa İstanbul by Using DEA-Window Analysis”, Sosyoekonomi, Vol. 27(42), 107-128.

Pjevčević, D. \& A. Radonjić \& Z. Hrle \& V. Čolić (2012), “DEA Window Analysis for Measuring Port Efficiencies in Serbia", Promet - Traffic \& Transportation, 24(1), 63-72.

Pulina, M. \& C. Detotto \& A. Paba (2010), “An investigation into the relationship between size and efficiency of the Italian hospitality sector: A window DEA approach", European Journal of Operational Research, 204, 613-620.

Ray, S.C. (2004), Data Envelopment Analysis Theory and Techniques for Economics and Operations Research, Cambridge University Press.

Řepková, I. (2014a), "Efficiency of the Czech banking sector employing the DEA window analysis approach", Procedia Economics and Finance, 12, 587-596.

Řepková, I. (2014b), "Efficiency of the Slovak Commercial Banks Applying the DEA Window Analysis", International Journal of Social, Management, Economics and Business Engineering, 8(5), 1330-1335.

Sharifian, S. \& A. Ebrahimi \& M. Alimohammadlou (2017), "An application of window data envelopment analysis methodology with double frontier in the performance assessment of Shiraz university colleges", Decision Science Letters, 6, 269-282.

Shawtari, F.A. \& M. Ariff \& S.H. Razak (2015), "Efficiency assessment of banking sector in Yemen using data envelopment window analysis a comparative analysis of Islamic and conventional banks", Benchmarking: An International Journal, 22(6), 1115-1140.

Sözen, A. \& İ. Alp (2009), “Comparison of Turkey’s performance of greenhouse gas emissions and local/regional pollutants with EU countries", Energy Policy, 37(12), 5007-5018.

Storto, C.I. \& B. Capano (2015), "A dynamic efficiency analysis of the European renewable energy capacity between 2002 and 2011", Advanced Materials Research, 1079-1080, 12741279.

Sueyoshi, T. \& M. Goto \& M. Sugiyama (2013), "DEA window analysis for environmental assessment in a dynamic time shift: Performance assessment of U.S. coal-fired power plants", Energy Economics, 40, 845-857.

Sufian, F. \& M.-Z.A. Majid (2007), "X-efficiency and share prices in the Singaporean banking sector: A DEA Window Analysis approach", Investment Management and Financial Innovations, 4(1), 73-90.

Wang, K. \& S. Yu \& W. Zhang (2013), “China's regional energy and environmental efficiency: A DEA window analysis based dynamic evaluation", Mathematical and Computer Modelling, 58, 1117-1127.

Webb, R.M. (2003), "Levels of Efficiency in UK Retail Banks: A DEA Window Analysis", International Journal of the Economics of Business, 10(3), 305-322.

Wu, H.-q. \& Y. Shi \& Q. Xia \& W.-d. Zhu (2014), "Effectiveness of the policy of circular economy in China: A DEA-based analysis for the period of 11th five-year-plan", Resources, Conservation and Recycling, 83, 163-175.

Yang, H.-H. \& C.-Y. Chang (2009), "Using DEA window analysis to measure efficiencies of Taiwan's integrated telecommunication firms", Telecommunications Policy, 33, 98-108.

Zhang, X.-P. \& X.-M. Cheng \& J.-H. Yuan \& X.-J. Gao (2011), "Total-factor energy efficiency in developing countries”, Energy Policy, 39, 644-650. 
Apan, M. \& İ. Alp \& A. Öztel (2019), "Determination of the Efficiencies of Textile Firms Listed in Borsa İstanbul by Using DEA-Window Analysis", Sosyoekonomi, Vol. 27(42), 107-128.

\section{Appendix:}

Tablo: 9

Window Analysis Results

\begin{tabular}{|c|c|c|c|c|c|c|c|c|c|c|c|c|c|c|}
\hline DMU & 2008 & 2009 & 2010 & 2011 & 2012 & 2013 & 2014 & 2015 & 2016 & 2017 & Mean & Std Deviation & Range & Rank no \\
\hline AKIN & 57.24 & $\begin{array}{l}64.95 \\
85.15\end{array}$ & $\begin{array}{r}88.71 \\
100 \\
100\end{array}$ & $\begin{array}{r}93.44 \\
99.93 \\
100\end{array}$ & $\begin{array}{r}100 \\
100 \\
89.09\end{array}$ & $\begin{array}{r}100 \\
89.10 \\
90.47\end{array}$ & $\begin{array}{l}100 \\
100 \\
100\end{array}$ & $\begin{array}{l}100 \\
100 \\
100\end{array}$ & $\begin{array}{r}99.70 \\
99.81 \\
100\end{array}$ & $\begin{array}{l}100 \\
100 \\
100 \\
\end{array}$ & 94.73 & 10.59 & 42.76 & 4 \\
\hline ARSAN & 61.06 & $\begin{array}{l}69.29 \\
70.02\end{array}$ & $\begin{array}{r}100 \\
78.03 \\
78.03\end{array}$ & $\begin{array}{l}100 \\
100 \\
100\end{array}$ & $\begin{array}{l}100 \\
100 \\
100\end{array}$ & $\begin{array}{l}100 \\
100 \\
100\end{array}$ & $\begin{array}{l}100 \\
100 \\
100\end{array}$ & $\begin{array}{l}93.95 \\
93.73 \\
96.60\end{array}$ & $\begin{array}{r}97.41 \\
100 \\
100\end{array}$ & $\begin{array}{l}100 \\
100 \\
100\end{array}$ & 94.000 & 11.30 & 38.94 & 5 \\
\hline BÍLİCI & 100 & $\begin{array}{r}90.55 \\
100\end{array}$ & $\begin{array}{l}100 \\
100 \\
100\end{array}$ & $\begin{array}{l}84.53 \\
84.53 \\
87.01\end{array}$ & $\begin{array}{l}74.20 \\
79.21 \\
72.14\end{array}$ & $\begin{array}{l}81.22 \\
76.27 \\
76.27\end{array}$ & $\begin{array}{l}100 \\
100 \\
100\end{array}$ & $\begin{array}{l}86.60 \\
86.52 \\
92.66\end{array}$ & $\begin{array}{l}70.21 \\
74.65 \\
79.86\end{array}$ & $\begin{array}{r}91.98 \\
100 \\
100\end{array}$ & 88.46 & 10.38 & 29.79 & 9 \\
\hline BİRKO & 54.36 & $\begin{array}{l}51.74 \\
59.02\end{array}$ & $\begin{array}{l}68.01 \\
69.25 \\
72.06\end{array}$ & $\begin{array}{l}73.23 \\
80.93 \\
83.35\end{array}$ & $\begin{array}{l}86.55 \\
92.99 \\
86.68\end{array}$ & $\begin{array}{l}77.25 \\
71.01 \\
73.06\end{array}$ & $\begin{array}{l}69.29 \\
70.29 \\
73.02\end{array}$ & $\begin{array}{l}70.46 \\
72.18 \\
67.37\end{array}$ & $\begin{array}{l}94.30 \\
79.59 \\
79.59\end{array}$ & $\begin{array}{l}100 \\
100 \\
100\end{array}$ & 76.87 & 12.74 & 48.26 & 16 \\
\hline BİRLİK & 55.40 & $\begin{array}{l}90.12 \\
80.48\end{array}$ & $\begin{array}{r}100 \\
82.40 \\
83.07\end{array}$ & $\begin{array}{l}82.36 \\
82.36 \\
87.91\end{array}$ & $\begin{array}{l}100 \\
100 \\
100\end{array}$ & $\begin{array}{l}54.45 \\
49.88 \\
49.88\end{array}$ & $\begin{array}{l}59.09 \\
56.63 \\
60.56\end{array}$ & $\begin{array}{r}100 \\
100 \\
67.37\end{array}$ & $\begin{array}{l}82.36 \\
79.59 \\
79.59\end{array}$ & $\begin{array}{l}100 \\
100 \\
100\end{array}$ & 80.87 & 17.61 & 50.12 & 13 \\
\hline BOSSA & 82.35 & $\begin{array}{l}63.34 \\
70.59\end{array}$ & $\begin{array}{l}58.97 \\
71.97 \\
81.33\end{array}$ & $\begin{array}{l}82.28 \\
87.68 \\
88.69\end{array}$ & $\begin{array}{l}82.12 \\
87.19 \\
73.04\end{array}$ & $\begin{array}{l}84.42 \\
77.08 \\
78.14\end{array}$ & $\begin{array}{l}81.64 \\
81.77 \\
88.33\end{array}$ & $\begin{array}{r}96.90 \\
100 \\
91.88\end{array}$ & $\begin{array}{l}99.71 \\
99.33 \\
99.33\end{array}$ & $\begin{array}{l}90.65 \\
90.65 \\
90.94\end{array}$ & 84.46 & 10.55 & 41.03 & 12 \\
\hline
\end{tabular}


Apan, M. \& İ. Alp \& A. Öztel (2019), "Determination of the Efficiencies of Textile Firms Listed in Borsa İstanbul by Using DEA-Window Analysis”, Sosyoekonomi, Vol. 27(42), 107-128.

\begin{tabular}{|c|c|c|c|c|c|c|c|c|c|c|c|c|c|c|}
\hline DAGI & 51.54 & $\begin{array}{l}52.35 \\
72.38\end{array}$ & $\begin{array}{l}64.37 \\
86.53 \\
90.92\end{array}$ & $\begin{array}{l}100 \\
100 \\
100\end{array}$ & $\begin{array}{l}78.23 \\
78.25 \\
64.22\end{array}$ & $\begin{array}{l}59.96 \\
55.98 \\
59.21\end{array}$ & $\begin{array}{l}74.63 \\
75.24 \\
77.69\end{array}$ & $\begin{array}{r}95.61 \\
100 \\
100\end{array}$ & $\begin{array}{l}67.01 \\
71.16 \\
73.11\end{array}$ & $\begin{array}{l}48.77 \\
54.11 \\
56.36\end{array}$ & 74.36 & 16.83 & 51.23 & 18 \\
\hline \begin{tabular}{|l|} 
DERİMOD \\
\end{tabular} & 47.71 & $\begin{array}{l}40.29 \\
55.79\end{array}$ & $\begin{array}{l}42.09 \\
58.78 \\
78.03\end{array}$ & $\begin{array}{l}59.31 \\
90.53 \\
99.41\end{array}$ & $\begin{array}{r}96.42 \\
100 \\
100\end{array}$ & $\begin{array}{l}100 \\
100 \\
100\end{array}$ & $\begin{array}{l}100 \\
100 \\
100\end{array}$ & $\begin{array}{l}100 \\
100 \\
100\end{array}$ & $\begin{array}{l}100 \\
100 \\
100\end{array}$ & $\begin{array}{r}97.68 \\
100 \\
100\end{array}$ & 87.63 & 20.57 & 59.71 & 10 \\
\hline DESA & 100 & $\begin{array}{r}100 \\
99.88\end{array}$ & $\begin{array}{r}100 \\
97.42 \\
100\end{array}$ & $\begin{array}{l}100 \\
100 \\
100\end{array}$ & $\begin{array}{l}100 \\
100 \\
100\end{array}$ & $\begin{array}{r}100 \\
90.93 \\
91.12\end{array}$ & $\begin{array}{l}100 \\
100 \\
100\end{array}$ & $\begin{array}{r}99.82 \\
99.82 \\
100\end{array}$ & $\begin{array}{r}89.2 \\
85.77 \\
87.44\end{array}$ & $\begin{array}{l}100 \\
100 \\
100\end{array}$ & 97.83 & 4.38 & 14.23 & 2 \\
\hline ESEM & 64.34 & $\begin{array}{l}18.07 \\
18.07\end{array}$ & $\begin{array}{l}100 \\
100 \\
100\end{array}$ & $\begin{array}{l}100 \\
100 \\
100\end{array}$ & $\begin{array}{r}90.67 \\
100 \\
100\end{array}$ & $\begin{array}{l}100 \\
100 \\
100\end{array}$ & $\begin{array}{r}99.56 \\
98.82 \\
100\end{array}$ & $\begin{array}{l}77.69 \\
74.79 \\
77.39\end{array}$ & $\begin{array}{l}56.16 \\
56.61 \\
56.61\end{array}$ & $\begin{array}{l}100 \\
100 \\
100\end{array}$ & 84.77 & 24.23 & 81.93 & 11 \\
\hline HATEKS & 79.10 & $\begin{array}{l}88.13 \\
81.05\end{array}$ & $\begin{array}{r}83.20 \\
100 \\
100\end{array}$ & $\begin{array}{r}97.90 \\
100 \\
100\end{array}$ & $\begin{array}{l}91.46 \\
95.20 \\
88.04\end{array}$ & $\begin{array}{l}85.31 \\
81.57 \\
82.34\end{array}$ & $\begin{array}{l}79.50 \\
79.53 \\
82.26\end{array}$ & $\begin{array}{l}84.40 \\
88.92 \\
86.09\end{array}$ & $\begin{array}{l}100 \\
100 \\
100\end{array}$ & $\begin{array}{l}100 \\
100 \\
100\end{array}$ & 90.89 & 8.17 & 20.90 & 6 \\
\hline KARSU & 49.90 & $\begin{array}{l}46.92 \\
54.32\end{array}$ & $\begin{array}{l}48.85 \\
59.39 \\
83.45\end{array}$ & $\begin{array}{l}54.80 \\
69.08 \\
77.36\end{array}$ & $\begin{array}{l}67.43 \\
72.38 \\
67.40\end{array}$ & $\begin{array}{l}66.29 \\
62.40 \\
66.17\end{array}$ & $\begin{array}{l}64.91 \\
68.31 \\
68.92\end{array}$ & $\begin{array}{l}75.48 \\
74.06 \\
76.79\end{array}$ & $\begin{array}{l}73.24 \\
77.27 \\
78.56\end{array}$ & $\begin{array}{l}88.55 \\
88.55 \\
89.42\end{array}$ & 69.27 & 11.59 & 42.5 & 19 \\
\hline KORDSA & 56.08 & $\begin{array}{l}64.62 \\
79.93\end{array}$ & $\begin{array}{l}64.16 \\
80.29 \\
93.61\end{array}$ & $\begin{array}{r}85.81 \\
93.48 \\
100\end{array}$ & $\begin{array}{l}89.96 \\
93.82 \\
89.91\end{array}$ & $\begin{array}{l}99.63 \\
98.76 \\
98.76\end{array}$ & $\begin{array}{l}100 \\
100 \\
100\end{array}$ & $\begin{array}{l}88.93 \\
89.60 \\
84.37\end{array}$ & $\begin{array}{l}94.30 \\
88.24 \\
89.94\end{array}$ & $\begin{array}{l}95.98 \\
97.99 \\
98.16\end{array}$ & 89.49 & 11.51 & 43.92 & 7 \\
\hline
\end{tabular}


Apan, M. \& İ. Alp \& A. Öztel (2019), "Determination of the Efficiencies of Textile Firms Listed in Borsa İstanbul by Using DEA-Window Analysis", Sosyoekonomi, Vol. 27(42), 107-128.

\begin{tabular}{|c|c|c|c|c|c|c|c|c|c|c|c|c|c|c|}
\hline LÜKSKA & 46.54 & $\begin{array}{l}52.81 \\
64.87\end{array}$ & $\begin{array}{l}65.30 \\
76.62 \\
95.44\end{array}$ & $\begin{array}{l}70.53 \\
92.30 \\
98.34\end{array}$ & $\begin{array}{r}96.28 \\
100 \\
94.02\end{array}$ & $\begin{array}{l}72.35 \\
64.76 \\
64.76\end{array}$ & $\begin{array}{l}75.65 \\
76.72 \\
78.10\end{array}$ & $\begin{array}{l}72.35 \\
73.51 \\
72.98\end{array}$ & $\begin{array}{l}81.28 \\
84.99 \\
86.82\end{array}$ & $\begin{array}{l}77.13 \\
77.13 \\
77.16 \\
\end{array}$ & 77.36 & 13.06 & 53.46 & 15 \\
\hline MENDERES & 75.79 & $\begin{array}{r}87.48 \\
100\end{array}$ & $\begin{array}{r}92.14 \\
100 \\
100\end{array}$ & $\begin{array}{l}100 \\
100 \\
100\end{array}$ & $\begin{array}{l}83.17 \\
89.44 \\
87.60\end{array}$ & $\begin{array}{r}100 \\
98.87 \\
99.28\end{array}$ & $\begin{array}{r}100 \\
100 \\
99.04\end{array}$ & $\begin{array}{r}100 \\
92.11 \\
92.02\end{array}$ & $\begin{array}{l}100 \\
100 \\
100\end{array}$ & $\begin{array}{l}100 \\
100 \\
100\end{array}$ & 96.18 & 6.35 & 24.21 & 3 \\
\hline SÖKTAŞ & 53.78 & $\begin{array}{l}52.21 \\
66.74\end{array}$ & $\begin{array}{l}57.39 \\
74.86 \\
77.65\end{array}$ & $\begin{array}{r}84.38 \\
84.91 \\
100\end{array}$ & $\begin{array}{l}77.33 \\
87.47 \\
95.86\end{array}$ & $\begin{array}{l}96.95 \\
98.57 \\
96.89\end{array}$ & $\begin{array}{r}100 \\
97.13 \\
96.10\end{array}$ & $\begin{array}{l}100 \\
100 \\
100\end{array}$ & $\begin{array}{l}100 \\
100 \\
100\end{array}$ & $\begin{array}{r}95.52 \\
95.52 \\
100\end{array}$ & 88.49 & 15.08 & 47.79 & 8 \\
\hline SÖNMEZ & 76.11 & $\begin{array}{l}100 \\
100\end{array}$ & $\begin{array}{l}100 \\
100 \\
100\end{array}$ & $\begin{array}{l}100 \\
100 \\
100\end{array}$ & $\begin{array}{r}96.46 \\
100 \\
97.15\end{array}$ & $\begin{array}{l}100 \\
100 \\
100\end{array}$ & $\begin{array}{l}100 \\
100 \\
100\end{array}$ & $\begin{array}{l}100 \\
100 \\
100\end{array}$ & $\begin{array}{l}100 \\
100 \\
100\end{array}$ & $\begin{array}{l}100 \\
100 \\
100\end{array}$ & 98.88 & 4.54 & 23.89 & 1 \\
\hline YATAŞ & 53.78 & $\begin{array}{l}60.28 \\
60.65\end{array}$ & $\begin{array}{l}63.04 \\
59.22 \\
63.60\end{array}$ & $\begin{array}{l}61.00 \\
64.12 \\
65.27\end{array}$ & $\begin{array}{l}60.92 \\
61.19 \\
62.10\end{array}$ & $\begin{array}{l}70.38 \\
73.22 \\
80.28\end{array}$ & $\begin{array}{l}79.99 \\
84.57 \\
78.40\end{array}$ & $\begin{array}{l}96.52 \\
89.68 \\
88.94\end{array}$ & $\begin{array}{l}94.95 \\
90.71 \\
90.71\end{array}$ & $\begin{array}{l}100 \\
100 \\
100\end{array}$ & 76.06 & 15.09 & 46.22 & 17 \\
\hline YÜNSA & 63.41 & $\begin{array}{l}67.18 \\
64.35\end{array}$ & $\begin{array}{l}69.27 \\
70.66 \\
76.15\end{array}$ & $\begin{array}{l}76.55 \\
81.01 \\
87.41\end{array}$ & $\begin{array}{l}74.47 \\
82.29 \\
84.56\end{array}$ & $\begin{array}{l}84.46 \\
87.45 \\
93.97\end{array}$ & $\begin{array}{r}92.81 \\
97.65 \\
100\end{array}$ & $\begin{array}{l}81.92 \\
79.69 \\
73.47\end{array}$ & $\begin{array}{l}62.53 \\
61.84 \\
61.84\end{array}$ & $\begin{array}{r}86.8 \\
86.80 \\
87.55\end{array}$ & 79.11 & 11.08 & 38.16 & 14 \\
\hline Mean & 64.66 & 69.57 & 82.53 & 89.33 & 88.02 & 84.37 & 88.88 & 89.53 & 87.29 & 94.09 & 85.77 & & & \\
\hline Standart deviation & 15.98 & 20.78 & 16.21 & 12.5 & 11.92 & 15.57 & 13.46 & 10.78 & 13.75 & 11.46 & 15.79 & & & \\
\hline Range & 53.46 & 81.93 & 57.91 & 45.2 & 39.08 & 50.12 & 43.37 & 32.63 & 43.84 & 51.23 & 81.93 & & & \\
\hline
\end{tabular}

